\title{
Analysis of Factors that Influence the Level of Need on the Implementation of Occupational Health and Safety Management System (OSHMS) in the Kediri District Office of Health Office, 2020
}

\author{
Yulita Amaliyasari ${ }^{1}$ and Yuly \\ Peristiowati $^{2}$ \\ ${ }^{1}$ Health Office, Kediri, \\ Indonesia \\ ${ }^{2}$ Master of HealthInstitute of \\ Health Sciences Strada Indonesia \\ Email: \\ lita.mary5@gmail.com
}

Received : January $13^{\text {th }} 2021$

Accepted : May $4^{\text {th }} 2021$

Published : May 20 2021

\section{ABSTRACT}

The Occupational Safety and Health Management System (OSHMS) is part of the overall management system needed in order to control risks related to work activities in order to achieve a safe, comfortable and productive workplace. Kediri District Health Office has not implemented OSHMS. This study aims to analyze the factors that influence the level of need for the implementation of OSHMS in the Kediri District Health Office. This type of research uses quantitative research with cross sectional design. The employee population is 133 people, the sample size is 100 people, the statistical test used is ordinal regression. The results showed the variable comfort level of work environment and occupational disease history where $p$ $<0.05$, while the work culture variable (Occupational Safety and Health/OSH behavior) and the level of satisfaction of infrastructure where $\mathrm{p}>0.05$. So it can be concluded that there is an influence between the comfort level of the work environment and the history of occupational diseases on the level of need for OSHMS application, and there is no influence between work culture (OSH behavior) and the level of satisfaction of infrastructure on the level of need for OSHMS implementation. The comfort level of the work environment has the most influence on the level of need for OSHMS implementation.

Keywords: Infrastructure, occupational diseases, behavior, work environment, management system

Copyright @ 2021 IIK STRADA Indonesia All right reserved.

International License.

\section{INTRODUCTION}

To achieve regional development goals in realizing ideals, in accordance with the 2016-2021 Kediri District Medium-Term Development Plan, the Health Office as one of the regional apparatus organizations has set a development vision that is in line with the regional development vision, namely "Creating a Healthy Kediri Regency Community. Independently and Fairly ". Therefore, the achievement of this vision will be successful if services to the community can be of quality and efficient, supported by a state apparatus that is healthy, competent, and adequate infrastructure.

One of the ways to make this happen is by implementing the Occupational Health and Safety Management System (OSHMS) as stated in the Regulation of the Minister of Health of the Republic of Indonesia Number 48 of 2016 concerning Office Work Safety and Health Standards, that office as one of the 
workplaces cannot be separated. from various potential hazards in the work environment that can affect the safety and health of the employees in it. The Occupational Safety and Health Management System (OSHMS) is part of the overall management system needed in order to control risks related to work activities in order to achieve a safe, comfortable and productive workplace.

Based on observation and interview data, there is no implementation of OSHMS at the Kediri District Health Office. In implementing OSHMS, of course there is not only commitment from the management (structural), but there must also be a synergy between all elements, in this case the employees of the Kediri District Health Office, from top management to the employee level. Synergy will occur if each of them has the same understanding or perception of the importance of implementing OSH in offices in the form of implementing OSHMS.

Therefore, this study aims to analyze the factors that influence the level of need regarding the application of OSHMS in the Kediri District Health Office. The results of this study are expected to provide benefits for the Kediri District Health Office as input for the implementation of OSHMS.

\section{MATERIALS AND METHODS}

This study uses a quantitative research approach. The analysis carried out is analytical. Based on data collection, the study design used an observational approach that was cross sectional. The population in this study were all employees of the Kediri District Health Office (except the Kediri District Hospital and Community Health Center) totaling 133 (one hundred and thirty three) people. The sample of this study were some of the employees of the Kediri District Health Office. Sampling is done by simple random sampling or simple random sampling using lottery numbers. Meanwhile, the determination of the sample size uses the Slovin formula. From the results of the formula, if rounded off, the sample size is 100 respondents.

The independent variables in this study are work environment, work culture/OSH behavior, satisfaction level of infrastructure, and work-related disease history. While the dependent variable is the level of need for the application of OSHMS. The data scale used in this study is the ordinal data scale. The data collection process in this study was taken from primary data and secondary data. Primary data by distributing questionnaires and secondary data by interviewing or taking existing data. The validity and reliability of the questionnaire was carried out at the Kediri City Health Office as many as 30 questionnaires and data validity testing was carried out using the SPSS software tool using the number (r) from the Corrected Item Total Correlation results through the Scale menu in the Reliability Analysis option. Reliability testing uses Alpha Cronbach measurements. While the test used in this study is the influence test. Tests were carried out with SPSS software tools using nonparametric ordinal regression tests.

\section{RESULTS}

In this study the values of $\mathrm{H}_{0}=0.05$ and $\mathrm{H}_{0}$ are as follows.

a. There is no influence between the comfort level of the work environment on the level of need for the application of OSHMS.

b. There is no influence between work culture (OSH behavior) on the level of need for the application of OSHMS.

c. There is no influence of the level of employee satisfaction with infrastructure on the need for implementing OSHMS.

d. There is no influence between the history of occupational diseases on the level of need for the application of OSHMS.

Based on the results of ordinal regression testing, the results obtained were two variables that had an $\mathrm{H}_{0}$ value less than 0.05 , namely the comfort level of the work environment and a history of occupational diseases, which means that $\mathrm{H}_{0}$ was rejected. While the work culture/OSH behavior variable and the level of satisfaction with infrastructure have a significant value greater than $\mathrm{H}_{0}$, which means that $\mathrm{H}_{0}$ is accepted. So from this explanation it can be concluded as follows. There is an influence between one of the categories of work environment comfort level variables on the level of need for the application of OSHMS with a significant value of 0.026 . There is no influence between all categories of work culture/OSH behavior variables on the level of need for the application of OSHMS with a significant value of 0.478 and 0.200 . There is no influence between all categories of the level of infrastructure and infrastructure satisfaction variables on the need for OSHMS implementation with a significant value of $0.856 ; 0.649$, and 0.811 . And there is an influence between one of the categories of occupational disease history variables on the level of need for OSHMS implementation with a significant value of 0.046 .

Judging from the significant value of the comfort level variable of the work environment and the history of work-related illnesses, the variable of the comfort level of the work environment has a 
significantly smaller value, namely 0.026 , this means that the variable that most influences the level of application needs of OSHMS is the comfort level of the work environment.

Table 4.5 Ordinal Regression Statistical Test Results

\begin{tabular}{|c|c|c|c|c|c|c|c|c|}
\hline & & \multirow{2}{*}{ Estimate } & \multirow{2}{*}{$\begin{array}{l}\text { Std. } \\
\text { Error }\end{array}$} & \multirow{2}{*}{ Wald } & \multirow{2}{*}{ df } & \multirow{2}{*}{ Sig. } & \multicolumn{2}{|c|}{$\begin{array}{l}\text { 95\% Confidence } \\
\text { Interval }\end{array}$} \\
\hline & & & & & & & $\begin{array}{l}\text { Lower } \\
\text { Bound }\end{array}$ & $\begin{array}{l}\text { Upper } \\
\text { Bound }\end{array}$ \\
\hline \multirow[t]{4}{*}{ Threshold } & $\begin{array}{l}\text { The level of need for } \\
\text { implementing OSHMS is } \\
\text { very unnecessary }\end{array}$ & $-2,300$ & ,554 & 17,256 & 1 & ,000 & $-3,385$ & $-1,215$ \\
\hline & $\begin{array}{l}\text { The level of need for the } \\
\text { application of OSHMS } \\
\text { does not require it }\end{array}$ & $-1,942$ & ,492 & 15,605 & 1 &, 000 & $-2,906$ &,- 979 \\
\hline & $\begin{array}{l}\text { The level of need for } \\
\text { application of OSHMS is } \\
\text { moderate }\end{array}$ & $-1,433$ & ,459 & 9,766 & 1 & ,002 & $-2,332$ &,- 534 \\
\hline & $\begin{array}{l}\text { The level of need for the } \\
\text { implementation of } \\
\text { OSHMS requires }\end{array}$ &,- 608 & ,444 & 1,881 & 1 &, 170 & $-1,478$ & ,261 \\
\hline \multirow[t]{16}{*}{ Location } & $\begin{array}{l}\text { The comfort level of the } \\
\text { work environment is not } \\
\text { very good }\end{array}$ &,- 730 & ,000 & & 1 & &,- 730 &,- 730 \\
\hline & $\begin{array}{l}\text { The comfort level of the } \\
\text { work environment is not } \\
\text { good }\end{array}$ &,- 705 & ,933 &, 571 & 1 &, 450 & $-2,534$ & 1,123 \\
\hline & $\begin{array}{l}\text { The comfort level of the } \\
\text { work environment is } \\
\text { moderate }\end{array}$ &,- 652 & ,389 & 2,805 & 1 & ,094 & $-1,414$ & ,111 \\
\hline & $\begin{array}{l}\text { The comfort level of the } \\
\text { work environment is good }\end{array}$ &,- 696 & ,312 & 4,987 & 1 & ,026 & $-1,308$ &,- 085 \\
\hline & $\begin{array}{l}\text { The comfort level of the } \\
\text { work environment is very } \\
\text { good }\end{array}$ & $0^{\mathrm{a}}$ & & & 0 & & & \\
\hline & $\begin{array}{l}\text { The level of work } \\
\text { culture/OSH behavior is } \\
\text { moderate }\end{array}$ & 431 & 608 & ,503 & 1 & ,478 &,- 760 & 1,623 \\
\hline & $\begin{array}{l}\text { The level of work } \\
\text { culture/OSH behavior is } \\
\text { good }\end{array}$ & ,361 & ,282 & 1,643 & 1 & ,200 &,- 191 & ,914 \\
\hline & $\begin{array}{l}\text { The level of work } \\
\text { culture/OSH behavior is } \\
\text { very good }\end{array}$ & $0^{\mathrm{a}}$ & & & 0 & & & \\
\hline & $\begin{array}{l}\text { The level of satisfaction } \\
\text { of infrastructure is not } \\
\text { very good }\end{array}$ & 3,260 & , 000 & & 1 & & 3,260 & 3,260 \\
\hline & $\begin{array}{l}\text { The level of satisfaction } \\
\text { of infrastructure is not } \\
\text { good }\end{array}$ & , 132 & ,727 & ,033 & 1 & ,856 & $-1,294$ & 1,557 \\
\hline & $\begin{array}{l}\text { The level of satisfaction } \\
\text { of infrastructure is } \\
\text { moderate }\end{array}$ &,- 212 & ,466 & ,207 & 1 & ,649 & $-1,126$ & ,701 \\
\hline & $\begin{array}{l}\text { The level of satisfaction } \\
\text { of infrastructure is good }\end{array}$ & , 104 & ,435 & ,057 & 1 &, 811 &,- 749 & ,957 \\
\hline & $\begin{array}{l}\text { The level of satisfaction } \\
\text { of infrastructure is very } \\
\text { good }\end{array}$ & $0^{\mathrm{a}}$ & & & 0 & & . & . \\
\hline & $\begin{array}{l}\text { History of occupational } \\
\text { diseases is moderate }\end{array}$ & $-1,742$ & ,873 & 3,980 & 1 & ,046 & $-3,453$ &,- 031 \\
\hline & $\begin{array}{l}\text { History of occupational } \\
\text { diseases is mild }\end{array}$ &,- 261 & 290 & ,809 & 1 & ,369 &,- 830 &, 308 \\
\hline & $\begin{array}{l}\text { History of occupational } \\
\text { diseases is very mild }\end{array}$ & $0^{\mathrm{a}}$ & & & 0 & & & . \\
\hline
\end{tabular}




\section{DISCUSSION}

\section{The Influence of Environmental Comfort Level on Needs on The Implementation of Oshms}

In this study, the independent variable level of work environment comfort has an influence on the level of need for the application of OSHMS. This is in line with the research on factors related to the implementation of OSHMS at PT. PLN (Persero) Sulselrabar Load Management Unit (Fadil Ismat, 2017), which is based on the results of statistical tests there is a relationship between the physical environment and the application of OSHMS where $\mathrm{p}<0.05$. In addition, in the study of the Influence of Knowledge, Attitudes, and Work Environment Conditions on Perceptions of Occupational Safety and Health Implementation (Arief Hartono, 2018), based on the results of statistical tests, it also shows that work environment conditions have a positive effect on perceptions of OSH implementation by $8.3 \%$.

According to Reza, 2017, one of the factors that influence human needs is the factor of natural conditions (environment). The environment will be closely related to the needs that humans must meet. Humans will make efforts and efforts to meet the needs based on the environment in which they are located. Likewise with the work environment, in this study the work environment affects the need for implementing OSHMS.

The work environment, seen from the parameters of physics, chemistry and microbiology, has an effect on the level of need regarding the application of OSHMS because the work environment is something that respondents encounter daily and is an important factor why someone needs to apply OSHMS in an office so that the work environment in the office is in accordance with the standards of the office work environment. which is safe and comfortable both in physics, chemistry, and microbiology. Good work environment standards are regulated in the Regulation of the Minister of Health of the Republic of Indonesia Number 48 of 2016 concerning Office Work Safety and Health Standards.

\section{The Influence of Work Culture (Behavior of Osh) on Needs on The Implementation of OSHMS}

Work culture or OSH behavior is the independent variable in the study that has no influence on the level of need for OSHMS implementation. This is in the study of the Effect of Workforce Behavior on the Implementation of OSHMS PT. Arto Metal Internasional (Geta Primadahani, 2015) with statistical test results there is no effect of workforce behavior on the application of OSHMS.

In this study, most of the respondents had good OSH behavior, although most of the respondents really needed the implementation of OSHMS. According to Maslow's hierarchy of needs (Wikipedia, 2019) there are five levels of basic needs, namely physiological needs, need for security, need for belonging and affection, need for appreciation, and need for self-actualization. After physiological needs are sufficiently satisfied, emerges what Maslow calls security needs. The need for security includes physical security, stability, dependence, protection, and freedom from threatening forces such as crime, war, terrorism, disease, fear, anxiety, danger, riots, and natural disasters.

Meanwhile, according to Rusman, 2019 the need for security is the need for security and protection from physical and emotional disorders. Almost all employees depend on their organization in terms of tranquility, supervision, decisions regarding their work. Therefore, although most of the respondent's OSH behavior is good, the need to implement OSHMS is considered to still need to be applied so that the need for security at work is met.

\section{THE INFLUENCE LEVEL OF FACILITIES SATISFACTION ON NEEDS OF OSHMS IMPLEMENTATION}

The independent variable of the level of satisfaction of the infrastructure in this study has no influence on the level of the need for implementing OSHMS. This is in line with the research on factors related to the implementation of occupational safety and health at the Denpasar City General Hospital (Kadek Eni Dwiari and Partha Muliawan, 2019), with the results of statistical tests on the availability of $\mathrm{OSH}$ Hospital facilities and infrastructure that are not significantly related to the implementation of OSH Hospital.

In this study, although most of the respondents were satisfied with the existing infrastructure, most respondents really needed the implementation of OSHMS. With the implementation of OSHMS in offices, the standard for infrastructure facilities has been regulated in the Regulation of the Minister of Health of the Republic of Indonesia Number 46 of 2016 concerning Office Work Safety and Health 
Standards, so it is not only based on the assumption of respondents that infrastructure is good, but also ergonomic standards and measurements standardized. Therefore, the level of infrastructure satisfaction has no effect on the level of need for OSHMS implementation. The implementation of OSHMS is still needed to improve the quality and quantity of existing infrastructure in order to comply with the requirements of office ergonomics standards.

\section{The Influence of History of Work-Due Diseases (Occupational Diseases) on The Need For OSHMS Application}

In this study, the independent variable of occupational disease history has an influence on the level of need for OSHMS application. This is in line with the research on the relationship between the implementation of the OSH program and the incidence of occupational diseases in employees of PT Lembah Karet, Padang City (Luthfil Hadi Anshari, 2015) which concluded that there is a significant relationship between the implementation of the OSH program and occupational diseases.

The existence of a disease that attacks the body, of course, will cause changes in the fulfillment of needs, both psychological and physiological. This is because some of the functions of the organs in the body require greater fulfillment than usual (Reza, 2017). Therefore, a history of occupational disease affects the need for OSHMS implementation. Respondents need safer and more comfortable conditions when working. The implementation of OSHMS is considered to be able to improve the safety and health of employees so that they do not experience work-related accidents / diseases or at least reduce the incidence of occupational accidents/diseases.

This is in line with the study of the Effect of OSHMS on the Level of Work Accidents and Worker Health in Construction Projects (Case Study: Sahid Kuta Lifestyle Resort 2) by Wahyu Andika Suwardana, Lilik Sudiajeng, and Iketut Sutapa, 2019. One of the factors that causes accidents and illness due to work is how the application of OSHMS to the project. This study aims to measure how much influence the implementation of OSHMS on frequency (frequency), OSHMS on severity, OSHMS on complaints, and OSHMS on fatigue in the Sahid Kuta Lifestyle Resort 2. The results of this study indicate that OSHMS has a significant effect on the frequency was $15.9 \%$, the severity was $11.9 \%$, the complaints were $39 \%$, and the fatigue was $29.1 \%$. Likewise with research on the Analysis of Occupational Health and Safety Management Systems at PT. PLN (Persero) Makasar City Tello Power Sector by A. Haslindah, Jamaluddin, and Gita Saputri Kasman, 2017 which aims to determine the level of effectiveness of OSHMS and how accidents and diseases that occur due to work at PT. PLN (Persero) Tello Power Sector. One of the conclusions of this research is accidents and diseases that occurred at PT. PLN (Persero) Tello Power Sector is still experienced by employees. Even so, accidents and diseases that occur due to work have been minimized as proven by the satisfactory level of OSHMS effectiveness.

\section{CONCLUSION}

Based on the results of the research that has been carried out and its discussion, the following conclusions can be drawn.

a. There is an influence of the comfort level of the work environment on the level of need for OSHMS implementation in the Kediri District Health Office. The work environment is an environmental condition encountered by respondents on a daily basis, the hope is that after implementing OSHMS, a work environment in the office will be created in accordance with the standards of a safe and comfortable office work environment both in physics, chemistry and microbiology.

b. There is no influence between work culture (OSH behavior) on the level of need for OSHMS implementation. Even though the respondent's OSH behavior has been good, respondents still need the application of OSHMS in order to increase the comfort, safety and work productivity of employees.

c. There is no influence between the level of satisfaction of the infrastructure on the level of need for OSHMS implementation. Although most respondents are satisfied with the existing infrastructure, the implementation of OSHMS must be implemented in order to improve the quality and quantity of existing infrastructure so that they are in line with the requirements of office ergonomics standards.

d. There is an influence between occupational disease history on the level of need for OSHMS implementation. The implementation of OSHMS is considered very much needed by employees 
in order to improve the safety and health of employees so as not to experience work accidents / diseases or at least reduce the incidence of occupational accidents / diseases.

e. Judging from the significant value of the comfort level variable of the work environment and the history of work-related illnesses, the variable of the comfort level of the work environment has a significantly smaller value, this means that the variable that most influences the level of application needs of OSHMS is the comfort level of the work environment.

Suggestions that can be conveyed based on the results of this study are as follows.

a. The Health Office as a major health agency in charge of other technical health implementation units, should immediately implement an Occupational Safety and Health Management System (OSHMS) so that employee safety and health are guaranteed and can increase the productivity of employee performance in serving the community.

b. $\quad$ For future researchers who use this study as a reference, it is better if data collection is not only obtained from respondents' perceptions, but also based on measurements using laboratory instruments and tests.

\section{ACKNOWLEDGMENTS}

The author would like thank to Allah SWT, to my husband, children, parents, and my beloved sister who have provided good moral and material support so far so that I was able to complete this thesis. Furthermore, thanks and highest appreciation to this thesis supervisor Dr. Yuly Peristiowatu, S.Kep., Ns., M.Kes, who provided guidance, corrections, and suggestions for the realization of this thesis. Then also thanks to: Prof. Dr. Sandu Siyoto, S.Sos., S.KM., M.Kes as the rector of IIK STRADA Indonesia Kediri, the lecturers who examined the proposal and thesis, all lecturers and staff of IIK STRADA Indonesia Kediri, head and all staff of Dinas Kesehatan Kabupaten Kediri, head and staff of the Badan Kesatuan Bangsa dan Politik Kabupaten Kediri, head and staff of Dinas Kesehatan Kota Kediri, head and staff of the Dinas Penanaman Modal dan Pelayanan Terpadu Satu Pintu Kota Kediri, friends of IIK STRADA Indonesia Kediri students, and all parties who have helped the smooth writing of this thesis which cannot be mentioned one by one.

\section{CONFLICTS OF INTEREST}

The author does not have a conflict of interest in this study.

\section{REFERENCES}

Anshari, Luthfil Hadi. (2015). Hubungan Pelaksanaan Program Keselamatan dan Kesehatan Kerja (K3) dengan Kejadian Penyakit Akibat Kerja (PAK) pada Karyawan PT. Lembah Karet Kota Padang. Retrieved from https://ojs.unud.ac.id/index.php/ach/article/download/59436/34526

Dwiari, Kadek Eni dan Partha Muliawan. (2019). Faktor yang Berhubungan dengan Pelaksanaan Keselamatan dan Kesehatan Kerja di Rumah Sakit Umum Kota Denpasar. Arc. Com. Health. $6(2): 17-29$.

Hartono, Arief dan Sutopo. (2018). Pengaruh pengetahuan, Sikap, dan Kondisi Lingkungan Kerja terhadap Persepsi Penerapan Keselamatan dan Kesehatan Kerja. Jurnal Dinamika Vokasional Teknik Mesin. 3(2):76-81.

Haslindah, A, Jamaluddin, dan Gita Saputri Kasman. (2017). Analisis Sistem Manajemen Keselamatan dan Kesehatan Kerja pada PT. PLN (Persero) Sektor Pembangkit Tello Kota Makassar. ILTEK. 12(24): 1755-1759.

Ismat, Fadil. (2017). Faktor yang Berhubungan dengan Penerapan Sistem Manajemen Keselamatan dan Kesehatan Kerja (SMK3) di PT. PLN (Persero) Unit Pengatur Beban Sulselrabar Tahun 2017. Retrieved from https://journal.uny.ac.id/index.php/dynamika/article/download/21$402 / 11167$

Primadhani, Getha. (2015). Pengaruh Perilaku Tenaga Kerja terhadap Penerapan Sistem Manajemen Keselamatan dan Kesehatan Kerja PT. Arto Metal Internasional. Retrieved from https://library.itats.ac.id/repository/S09-1351ABSTRAK_\%20ABSTRACT_\%20KA-

TA\%20PENGANTAR.pdf 
Reza. (2017). Faktor yang Mempengaruhi Kebutuhan Manusia. Retrieved from https://materiips.com/faktor-yang-mempengaruhi-kebutuhan-manusia

Rusman. (2019). Artikel, Teori Kebutuhan Maslow. Retrieved from https://www.kompasiana.com/rusrusman522/5bcee2f56ddcae67504635c2/lebih-rinci-tentang-teori-kebutuhanmaslow?page=all\#sectionall

Suwardana, Wahyu Andika, Lilik Sudiajeng, dan I Ketut Sutapa. (2019). Pengaruh SMK3 terhadap Tingkat Kecelakaan Kerja dan Kesehatan Pekerja pada Proyek Konstruksi (Studi Kasus: Sahid Kuta Lifestyle Resort 2). Prosiding Seminar Nasional Ketekniksipilan Bidang Vokasional. 1(1): 295-300.

Wikipedia. (2019). Hierarki Kebutuhan Maslow. Retrieved from https://id.wikipedia.org/wiki/Hierarki_kebutuhan_Maslow 